\title{
POVIJEST KNJIŽNICA U ZAPREŠIĆU I OKOLICI
}

\author{
HISTORY OF LIBRARIES IN ZAPREŠIĆ AREA
}

\author{
Marija Bartolić \\ Knjižnice grada Zagreba \\ marija.bartolic@kgz.hr \\ Janja Severović \\ Knjižnice grada Zagreba \\ janja.severovic@kgz.hr \\ Vlasta Šolc \\ Knjižnice grada Zagreba \\ vlasta.solc@kgz.hr
}

UDK / UDC 021(497.5 Zaprešić)(091)

Izvorni znanstveni rad / Original scientific paper

Primljeno / Received: 15. 4. 2020.

Prihvaćeno / Accepted: 18. 6. 2020.

\section{Sažetak}

Cilj. Cilj je rada na temelju literature, dokumenata te informacija kojima raspolažu ravnatelji i voditelji pojedinih knjižnica otkriti, prikupiti i analizirati podatke te izraditi što vjerodostojniji sustavan pregled razvoja knjižnica na području Zaprešića i okolice od osnutka prve knjižnice do kraja 2018. godine.

Pristup/metodologija. Istraživanju se pristupilo iščitavanjem literature i dostupnih dokumenata. Budući da se utvrdilo da su informacije u tim izvorima nedostatne, knjižnicama Zaprešića i okolice poslan je upitnik s pitanjima o razvoju i aktualnom stanju, na koji su sve odgovorile. Istraživanjem su obuhvaćene sve knjižnice koje djeluju ili su djelovale na području Zaprešića i okolice (narodne, školske i visokoškolska).

Rezultati. Na temelju literature i odgovora ravnatelja ili voditelja knjižnica prikazan je razvoj knjižnica Zaprešića i okolice prema vrstama knjižnica te unutar pojedinih vrsta kronološki. Nastojalo se ponuditi potpunu sliku o radu svake knjižnice, od podataka o

Vjesnik bibliotekara Hrvatske 63, 1-2(2020), 283-308 ISSN 0507-1925 
osnutku i najvažnijih informacija iz prošlosti, zaključno s aktualnim stanjem i djelovanjem. Ustanovljeno je da knjižnice međusobno vrlo dobro i često surađuju. Pokazano je da su na području Zaprešića i okolice knjižnice bile i ostale važan čimbenik života naselja te da idu ukorak s promjenama i razvojem u knjižničarskoj struci i društvu općenito.

Originalnost/vrijednost. Rad nudi prvi sustavan pregled razvoja knjižnica Zaprešića i okolice. Tijekom istraživanja pronađeno je te u radu prikazano više nepoznatih ili manje poznatih informacija o knjižnicama koje bi mogle biti vrijedne budućim istraživačima.

Ključne riječi: knjižnice, narodne knjižnice, povijest knjižnica, školske knjižnice, Zaprešić

\begin{abstract}
Purpose. The purpose of this paper is to collect information from the professional and scientific literature, documents and records, and interviews with library directors in order to analyze facts and make a more comprehensive, systematic overview of the development of libraries in Zaprešić and its surrounding area from the foundation of the first library until the end of 2018.
\end{abstract}

Approach/methodology. The approach was a systematic search of the professional literature and available documents. It was concluded that the information in these sources were insufficient and it was decided to prepare a questionnaire with the questions about the development and current status of the libraries, which was sent to the libraries in Zaprešić and surrounding area. All the libraries responded to the questionnaire. The survey covered all libraries in the Zaprešić area (public, school, and university libraries).

Findings. A detailed analysis of the literature and responses of the library directors and librarians was performed and the development of libraries in Zaprešić and surrounding area was presented. The presentation was made according to the type of libraries and chronologically. The aim was to show the complete picture of all libraries from the beginning and to the present state and activities. The results have shown that the libraries cooperate very well and very often. Also, it was observed that in the Zaprešić area the libraries have always played a very important role in everyday life of the community in the past and present, and that they are keeping pace with the modern changes in society and the development of library profession.

Originality/value. This paper offers the first systematic review of libraries in Zaprešić and surrounding area. During the research process, a number of mostly unknown or less known facts about the libraries were revealed which could be invaluable to future researchers.

Keywords: history of libraries, libraries, public libraries, school libraries, Zaprešić 


\section{Uvod}

Sustavno istraživanje cjelokupnog razvoja knjižnica Zaprešića i okolice dosad nije provedeno, a dosadašnje informacije o knjižnicama u tom kraju fragmentarne su, raspršene i nedovoljno istražene. Međutim i tako nedostatne daju naslutiti bogatu, razgranatu i zanimljivu povijest vrijednu istraživanja.

Ovim se radom nastoji istražiti i prikazati povijesni razvoj knjižnica na širem području Zaprešića koje obuhvaća grad Zaprešić te sedam općina koje mu u geografskom, društvenom i kulturnom smislu gravitiraju - Bistru, Brdovec, Dubravicu, Jakovlje, Luku, Mariju Goricu i Pušću. Te su se općine u prošlosti administrativno ispreplitale, da bi u drugoj polovici 20. stoljeća bile dijelom jedinstvene Općine Zaprešić. U nastavku članka navedeno se područje naziva „Zaprešić i okolica“. Istraživanje obuhvaća razdoblje od prvih zapisa o knjižnici u školi u Brdovcu 1875. ${ }^{1}$ do kraja 2018. godine.

\section{Kontekst društvenog i kulturnog razvoja Zaprešića i okolice}

Područje istraživanja, Zaprešić i okolica, smješteno je u sjeverozapadnom dijelu Zagrebačke županije. Naseljeno je od kamenog doba. Iz srednjeg vijeka datiraju prvi dokumenti o naseljima, a veću pozornost skrenulo je na sebe 1573. kada je dalo više istaknutih suboraca Matije Gupca tijekom Seljačke bune. Na prijelazu iz 19. u 20. stoljeće bilježi društveni i ekonomski razvoj te je jedno od ishodišta prosvjeda protiv mađarizacije, a u nastavku 20. stoljeća dolazi do industrijalizacije i demografskog rasta. ${ }^{2}$ Nakon Drugog svjetskog rata Zaprešić postaje dijelom Grada Zagreba, a krajem 70 -ih i početkom 80 -ih godina 20 . stoljeća, zahvaljujući blizini Zagreba i programu dislokacije zagrebačke privrede, zaprešićka industrija kontinuirano raste. ${ }^{3} \mathrm{~S}$ vremenom su Zaprešić i okolica postali sve bolje prometno povezani sa Zagrebom i međusobno. Demografski i gospodarski rast pratio je i razvoj društvenog i kulturnog života. Zaprešić dobiva status grada 1995. godine ${ }^{4}$ te se zajedno s okolicom počinje nešto samostalnije razvijati iako i dalje ostaje značajno vezan za Zagreb.

Zaprešić je prema posljednjem popisu stanovništva najgušće naseljen grad Zagrebačke županije s 467,6 stanovnika po kvadratnom kilometru, bilježi demografski rast ${ }^{5}$

\footnotetext{
1 Spomenica škole Brdovec. // Brdovečki zbornik 3(2004), str. 201.

2 Zaprešić: stambeno-komunalna monografija. Zaprešić: Samoupravna interesna zajednica stanovanja i komunalnih djelatnosti, 1990. Str. 22-25.

3 Blažić, Z. Razvoj općine Zaprešić od 1963. do 1995.: diplomski rad. Zagreb: Filozofski fakultet, Odsjek za povijest, 2019. Str. 57.

4 Zaprešić. // Hrvatska enciklopedija. Zagreb: Leksikografski zavod Miroslav Krleža, 2019. [citirano: 2019-09-09]. Dostupno na: http://www.enciklopedija.hr/natuknica.aspx?ID=66895\#top.

5 Popis stanovništva, kućanstava i stanova 2011: stanovništvo prema spolu i starosti. Zagreb: Državni zavod za statistiku, 2013. [citirano: 2019-12-18]. Dostupno na: https://www.dzs.hr/Hrv_ Eng/publication/2012/SI-1468.pdf.
} 
te je grad s najvišim udjelom visokoobrazovanog stanovništva u Zagrebačkoj županiji. ${ }^{6}$ Stanovnici tog područja pretežno rade u Zagrebu ${ }^{7}$, ali stanovanje, slobodno vrijeme i obiteljski život grade na području Zaprešića i okolice koje je financijski pristupačnije, dobro prometno povezano te sve bogatije društvenim i kulturnim sadržajima.

Značajan doprinos društveno-kulturnom razvoju dale su upravo knjižnice odigravši veliku ulogu u pismenosti najprije ruralnog, zatim radničkog, a sada sve urbanijeg stanovništva. Neke su u međuvremenu prestale postojati, neke su se otvorile, a neke zavidno dugo, kontinuirano i uspješno rade.

\section{Metodologija}

Metodologija rada sastojala se od istraživanja rada knjižnica svih vrsta na području Zaprešića i okolice proučavanjem literature i dokumenata i anketnim upitnikom. U vrijeme istraživanja na tom području djeluje 16 knjižnica: 12 školskih, 3 narodne i 1 visokoškolska. Do informacija o prošlosti knjižnica došlo se temeljitim iščitavanjem literature i dokumenata: spomenica škola (neke su objavljene u Zaprešićkim godišnjacima, a za pristup drugima zamolilo se škole, koje su to i omogućile), izvještaja i stručnih publikacija o Zaprešiću i okolici. U slučaju nedostatka relevantne literature, a postojanja pouzdane osobe koja se sjeća okolnosti rada knjižnice, za izvor se rabilo svjedočanstvo te osobe. Pretraživanje arhivske građe nije bilo bez izazova, osobito u istraživanju prošlosti školskih knjižnica čije spomenice nisu objavljene. Također u nekim se spomenicama školske knjižnice rijetko i šturo spominju pa je njihov rad bilo vrlo teško rekonstruirati. Stoga su poglavlja o nekim školskim knjižnicama siromašnija povijesnim informacijama i izvorima.

Aktualne informacije dobivene su anketnim upitnikom koji je poslan knjižnicama Zaprešića i okolice na koji je odgovorilo svih 16 knjižnica tijekom lipnja 2019. godine. Upitnik je pripremljen u elektroničkom obliku. Odgovarali su školski knjižničari te ravnatelji ili voditelji narodnih knjižnica i visokoškolske knjižnice. Pitanjima se nastojalo obuhvatiti opće podatke o poslovanju i programima knjižnica: broj zaposlenih, broj članova, posudbu građe, veličinu fonda 2018. godine, izvore financiranja, način nabave građe, broj tjednih sati koje je knjižnica otvorena za korisnike, zastupljenost pojedinih vrsta građe, uporabu knjižničnih programa, organizaciju građe u posebne zbirke, organiziranje $i / i$ ili sudjelovanje $u$

\footnotetext{
6 Popis stanovništva, kućanstava i stanova 2011: stanovništvo prema obrazovnim obilježjima. Zagreb: Državni zavod za statistiku, 2016. [citirano: 2019-12-17]. Dostupno na: https://www.dzs. hr/Hrv_Eng/publication/2016/SI-1582.pdf

7 Rajić, N. Stručna podloga za izradu novog Prostornog plana Zagrebačke županije iz područja demografije. Zagreb: Zavod za prostorno uređenje Zagrebačke županije, 2015. Str. 34. Dostupno na: https://www.zpuzz.hr/cms_files/2017/11/1511433301_novi-pp-zz-elaborat-demografija-2015.pdf.
} 
odgojno-obrazovnim i kulturnim projektima i programima te programima za poticanje čitanja, suradnju s drugim knjižnicama i ustanovama, digitalizaciju građe, prisutnost na internetu i društvenim mrežama te nakladničku djelatnost knjižnica. Odgovori su temeljeni na podacima iz knjižničnih programa i znanju ispitanika. Pitanje o načinu nabave građe imalo je višestruke odgovore (kupnja, dar, zamjena, vlastita izdanja, obvezni primjerak), ostala su bila otvorenog tipa. Sve su knjižnice odgovorile na sva pitanja, osim knjižnice Osnovne škole Kupljenovo koja zbog radova i selidbe nije imala zabilježene sve aktualne podatke.

U nastavku rada prikazani su razvoj i sadašnje poslovanje knjižnica prema vrstama knjižnica te unutar pojedinih vrsta kronološki, prema godini početka poslovanja.

\section{Knjižnice Zaprešića i okolice}

Za razvoj kulturnog života u Zaprešiću i okolici u 19. stoljeću ključno je osnivanje škola čime se podigla razina pismenosti. Potkraj 19. stoljeća tek je trećina stanovništva znala čitati i pisati, a 1910 . gotovo polovina. ${ }^{8}$ Prve su knjižnice u Zaprešiću i okolici bile školske knjižnice. Kako je u drugoj polovini 19. stoljeća propisano, školskim knjižnicama smjeli su se rabiti i odrasli ${ }^{9}$ pa se može pretpostaviti da su i školske knjižnice Zaprešića i okolice bile otvorene i ostalim zainteresiranim mještanima. Krajem 19. i u prvoj polovici 20. st. počinju se osnivati prve narodne čitaonice i knjižnice koje su, osim u širenju tiska i knjige, imale značajnu ulogu u cjelokupnom prosvjetno-kulturnom životu toga doba. Početkom 21. stoljeća otvara se jedina visokoškolska knjižnica na tom području - Knjižnica Veleučilišta Baltazar Zaprešić. ${ }^{10} \mathrm{U}$ vrijeme istraživanja na tom području djeluju 12 školskih, 3 narodne i 1 visokoškolska knjižnica.

\section{1. Školske knjižnice}

U odnosu na druge vrste knjižnica u Hrvatskoj školske su knjižnice prve uređene zakonskim i drugim propisima. Iako su na području današnje Hrvatske djelovale i ranije, njihovo je postojanje pravno uređeno 1849. godine temeljem Osnova temeljnih pravilah javnog obučavanja za Hrvatsku i Slavoniju ${ }^{11}$ u kojima se nalazi odredba o obveznom osnivanju knjižnica u svakoj školi. Uslijedio je Zakon o škol-

\footnotetext{
8 Zaprešić: stambeno-komunalna monografija. Nav. dj., str. 17.

9 Stipanov, J. Povijest knjižnica i knjižničarstva u Hrvatskoj: od početaka do današnjih dana. Zagreb: Školska knjiga, 2015. Str. 163.

10 Zaprešić: monografija / glavna urednica Višnja Goljački. Zaprešić: Grad Zaprešić, 2015., str. 232.

11 Osnova temeljnih pravilah javnog javnoga obučavanja za Hervatsku i Slavoniu (1849). // Anali za povijest odgoja 1, 1(1992), str. 125-152.
} 
stvu u banskoj Hrvatskoj 1874. godine ${ }^{12}$ koji propisuje da svaka općina financira knjižnicu o kojoj će brigu voditi učitelj. Stipanov objašnjava da su u školama postojale učiteljske i učeničke knjižnice ta da je zamišljeno da se školskim knjižnicama mogu služiti i ostali odrasli stanovnici, što znači da su one trebale imati i ulogu današnje narodne knjižnice. ${ }^{13} U$ pojedinim naseljima Zaprešića i okolice $u$ to su vrijeme djelovale školske knjižnice. Prema pisanim izvorima, prva školska knjižnica spominje se u pučkoj školi u Brdovcu 1875. godine. ${ }^{14}$ Nije isključeno da je u nekim školama postojala knjižnica i ranije nego što je u ovom članku navedeno, ali o tome nema dostupnih pisanih izvora. Najranije su školske spomenice selektivne te tek povremeno spominju knjižnice. Također zbog političkih i ideoloških promjena iz njih su se nerijetko uklanjali višegodišnji zapisi. U tim se spomenicama spominju učeničke i učiteljske knjižnice. Učiteljske redovito imaju veći fond pa se može reći da su prve školske knjižnice bila namijenjene više učiteljima nego učenicima.

Neke od prvih školskih knjižnica imaju kontinuitet do danas, dok druge više ne postoje jer su nekadašnje pučke škole postale područne pa knjižničnu djelatnost za njih obavljaju školske knjižnice matičnih škola. Od 1903. do 1960. samostalno je djelovala škola u Jablanovcu. ${ }^{15}$ Niža pučka škola otvorena je 1903. godine, a 1960. postala je područna škola Osnovne škole Bistra, što je i danas. Školska knjižnica osnovana je u prvoj školskoj godini i sadržavala je 38 darovanih knjiga. U nastavku Spomenice pisane do 1948. godine knjižnica se više ne spominje. ${ }^{16}$ Školu u Laduču pokrenuo je svećenik Pavao Belas oko $1854 .{ }^{17} \mathrm{Ta}$ je škola radila dvadesetak godina, nakon čega su djeca išla u školu u Šenkovec. U Laduču se 1923. drugi put otvara škola ${ }^{18}$, a 1925. spominje se da je knjižnica bila opremljena potrebnim knjigama za djecu. ${ }^{19}$ Ništa od tog fonda nije sačuvano. Škola je već desetljećima područna škola Osnovne škole Ivane Brlić-Mažuranić u Prigorju Brdovečkom.

Između dva rata opremljenost školskih knjižnica pada toliko da gube sposobnost ispunjavanja svoje primarne zadaće, ali je još jednom propisana obveza da

12 Zakon od 14. listopada 1874. ob ustroju pučkih školah i preparandijah za pučko učiteljstvo u kraljevini Hrvatskoj i Slavoniji. // Sbornik zakonah i naredbah valjanih za kraljevinu Hrvatsku i Slavoniju 20(1874). [citirano: 2019-12-20]. Dostupno na: http://alex.onb.ac.at/cgi-content/ alex? aid $=1 \mathrm{ks} \&$ datum $=1874 \&$ size $=40 \&$ page $=413$.

13 Stipanov, J. Nav. dj., str. 163.

14 Spomenica škole Brdovec. Nav. dj., str. 201.

15 Spomenica za nižu pučku školu u Jablanovcu (1903 - 1948). // Zaprešićki godišnjak 13(2003), str. 123-171.

16 Isto, str. 126.

17 Debeljak, M. Laduč: 1446. - 1996. Laduč: Mjesni odbor, 1996. Str. 26.

18 Isto, str. 31.

19 Crtice iz povijesti školske knjižnice. // Osnovna škola Ivane Brlić-Mažuranić Prigorje Brdovečko. [citirano: 2020-03-22]. Dostupno na: http://www.os-ibmazuranic-prigorjebrdovecko. skole.hr/skola/knjiznica/o_knji_nici. 
školske knjižnice budu otvorene javnosti. ${ }^{20}$ Iako su prve imale zakonsko uporište, školske su se knjižnice sporije razvijale zbog nedovoljne financijske potpore i stručnog kadra. ${ }^{21}$ Situacija sa stručnim kadrom s vremenom se znatno popravila, ali opremljenost i u današnje vrijeme ovisi o sluhu nacionalne i lokalne vlasti. Prema važećem Standardu ${ }^{22} \mathrm{u}$ školskim knjižnicama trebaju raditi stručni suradnici knjižničari, a fond ne smije biti manji od 2.500 jedinica knjižnične građe, tako da se prve knjižnice Zaprešića i okolice u trenutku ovog istraživanja ne bi mogle nazvati školskim knjižnicama. Međutim piše se o njima jer su u naseljima u kojima su djelovale imale značajnu ulogu jedinih kulturnih institucija.

\subsubsection{Knjižnica Osnovne škole Pavao Belas, Brdovec}

Osnovna škola Pavao Belas nosi naziv po župniku koji je osnovao pučku školu u Brdovcu 1854. godine. ${ }^{23}$ Prvi se put školska knjižnica u brdovečkoj školi spominje 1875 . godine i tada je imala 78 svezaka. ${ }^{24} 1954$. brdovečka škola postaje područna škola Osnovne škole Antuna Augustinčića u Zaprešiću, a novoosnovana osmogodišnja Osnovna škola Pavao Belas počela je s radom 2009. godine. Odmah je otvorena knjižnica u kojoj radi diplomirana knjižničarka.

U godini otvorenja knjižnica je imala 207 članova, a 2018. godine 479. Iste je godine u fondu bilo 2983 jedinica građe, a posuđeno je 1764 jedinica građe. Građu nabavlja kupnjom, darom i zamjenom, a financira se iz sredstava Zagrebačke županije i iz vlastitih sredstava. Fond se sastoji od tiskanih knjiga (98 \%) te AVE-građe (2\%). Organizira programe knjižnično-informacijske i medijske pismenosti te provodi projekte za poticanje čitanja Naša mala knjižnica i Čitamo $m i, u$ obitelji svi. Uključena je u projekte Gradske knjižnice Ante Kovačića iz Zaprešića. Tjedno je za korisnike otvorena 30 sati, a 2010. godine u poslovanje je uveden računalni program Metelwin. Ima mrežnu stranicu u sklopu mrežne stranice škole. Knjižnica se bavi nakladništvom, objavila je dva djela.

\subsubsection{Knjižnica Osnovne škole Luka, Luka}

U Luci se škola otvorila 1874. godine. Postojanje knjižnice prvi se put spominje između 1875. i 1880. godine. ${ }^{25} \mathrm{U}$ školskoj spomenici piše da se ,školska knjižnica nalazi u pouzdano napredujućem stadiju" te da sadrži 20 djela u učiteljskoj i 30 u učeničkoj knjižnici. Fond usprkos financijskim preprekama raste pa 1908.

\footnotetext{
20 Stipanov, J. Nav. dj., str. 210.

21 Isto, str. 234-235.

22 Standard za školske knjižnice. // Narodne novine 34, 698(2000). [citirano: 2020-03-07]. Dostupno na: https://narodne-novine.nn.hr/clanci/sluzbeni/2000_03_34_698.html.

23 Spomenica škole Brdovec. Nav. dj., str. 201.

24 Isto, str. 203.

25 Spomenica za nižu pučku školu u Luki od godine 1874. // Zaprešićki godišnjak 15/16(2005/2006), str. 47.
} 
učiteljska knjižnica ima 294, a učenička 197 svezaka. ${ }^{26}$ 1912. otvorena je nova školska zgrada u kojoj se nastava održava i danas, ali o knjižici nema zapisa sve do razdoblja od 1943. do 1945. kada se spominje velika šteta nastala boravkom vojske u školi koja je zapalila arhivu i knjižnicu. ${ }^{27}$

Suvremena školska knjižnica Osnovne škole Luka osnovana je 2007. kada je škola odvojena od Osnovne škole Kupljenovo i tada je posao školskog knjižničara obavljao profesor hrvatskog jezika zaposlen na pola radnog vremena. U trenutku istraživanja u knjižnici radi diplomirana knjižničarka. Najraniji zabilježeni podaci su iz 2013. kada je imala 148 članova i posudbu od 599 jedinica građe. Početni fond knjižnice u prvoj godini rada iznosio je 500 jedinica građe, dok ih je 2018. imala 6300, kada je posuđena 351 jedinica građe. Građu nabavlja putem kupnje i dara, a financira se vlastitim sredstvima, iz sredstava Ministarstva znanosti i obrazovanja te sredstvima donatora. Knjižnica ima $95 \%$ tiskane građe i $5 \%$ AVE-građe. Tjedno je za korisnike otvorena 20 sati. Knjižnični program Metelwin uveden je u poslovanje 2013. godine. Ima mrežnu stranicu u sklopu stranice škole. Knjižničarka organizira satove knjižnično-informacijske pismenosti, projekte, radionice, kvizove, predavanja za učenike te programe poticanja čitanja poput čitanja priča i bajki. Sudjeluje u projektima i programima Gradske knjižnice Ante Kovačića i Bibliobusa Knjižnica grada Zagreba.

\subsubsection{Knjižnica Osnovne škole Bistra, Poljanica Bistranska}

Osnovna škola Bistra iz Poljanice Bistranske osnovana je 1848. godine. Prvi je zapis o postojanju knjižnice iz školske godine 1895./1896. kada je učiteljska knjižnica imala 155 svezaka, a učenička $133 .^{28}$

U knjižnici 2018. radi diplomirana knjižničarka. Ima 660 članova te fond od 5885 knjiga i 71 jedinice AVE-građe. Građu nabavlja kupnjom iz proračunskih sredstava Općine Bistra, donacijom i darom te se sufinancira izdavanjem vlastitih izdanja. Fond čine tiskane knjige (95\%) te časopisi, AVE-građa i društvene igre (5\%). Od posebno izdvojenih zbirki knjižnica ima AVE-zbirku. Provodi obrazovno-odgojne i kulturne programe: Čitamo mi, u obitelji svi, Dani knjige, Dan materinjeg jezika, Čitajmo zajedno, Čitajmo naglas, Zaboravljene knjige. Organiziraju se susreti s književnicima te posjeti knjižnici. Knjižnica surađuje s Općinskom knjižnicom Bistra te sudjeluje u međunarodnim projektima s Hrvatskim školskim centrom Miroslava Krleže iz Pečuha. Za korisnike je otvorena 30 sati tjedno. Računalni program Zaki uveden je u poslovanje 2009. godine. Informacije o knjižnici moguće je pronaći na mrežnoj stranici škole. Knjižnica sudjeluje u nakladničkoj djelatnosti škole koja je dosad objavila pet knjiga.

\footnotetext{
26 Isto, str. 82.

27 Isto, str. 141.

28 Bistra: monografija / ur. Ljiljana Dobrovšak. Bistra: Općina Bistra, 2014. Str. 192.
} 


\subsubsection{Knjižnica Osnovne škole Antuna Augustinčića, Zaprešić}

Zaprešićki učenici pohađali su školu u Brdovcu 50 godina sve dok 1904. godine u Zaprešiću nije otvorena Pučka škola „Jelačić ban“. ${ }^{29}$ Knjižnica se prvi put spominje 1907. godine, sadržavala je 16 svezaka za učenike i 56 za učitelje. ${ }^{30} 1953$. s radom počinje Narodna osmogodišnja škola „Zaprešić“, 1990. godine dovršena je nova školska zgrada, a škola je u međuvremenu dobila ime OŠ Antuna Augustinčića.

Knjižnica 2018. ima 10209 jedinica građe, 900 članova te posudbu od 4153 jedinice građe. Građu nabavlja darom, kupnjom iz sredstava Ministarstva znanosti i obrazovanja i Grada Zaprešića te iz vlastitih sredstava. Ima $85 \%$ tiskane i $15 \%$ AVE-građe. Otvorena je za korisnike 30 sati tjedno. Program Metelwin uveden je u poslovanje 2005. godine. Ima mrežnu stranicu u sklopu mrežne stranice škole. Organizira edukativne radionice po razredima, satove lektire, pričaonicu i čitaonicu. Sudjeluje u projektima obližnje Gradske knjižnice Ante Kovačića.

\subsubsection{Knjižnica Osnovne škole Pušća, Donja Pušća}

Na području današnje Općine Pušća prvi se put škola, prema usmenoj predaji, spominje 1848. godine, dok prvi zapisi o školi datiraju iz $1858 .{ }^{31}$ Najstariji podatak o radu knjižnice nalazi se u inventarnoj knjizi u koju je prvi inventarni broj upisan 1958. godine.

U knjižnici 2018. radi diplomirana knjižničarka. Fond sadrži 7439 jedinica građe te je u knjižnicu učlanjeno 439 članova. Iste je godine posuđeno 2746 jedinica građe. Građu knjižnica nabavlja kupnjom i darom, kupuje sredstvima Ministarstva znanosti i obrazovanja te iz prihoda škole. Od građe posjeduje $94 \%$ knjižne građe, $5 \%$ časopisa i novina i $1 \%$ AVE-građe. Ima posebne zbirke: Zbirku stare i rijetke građe, Zavičajnu zbirku i AVE-zbirku. Tjedno je za korisnike otvorena 30 sati i posluje uz pomoć računalnog programa Metelwin. Ima mrežnu stranicu u sklopu stranice škole. Knjižničarka provodi nastavu knjižnično-informacijske pismenosti, vodi grupu Mali knjižničari, provodi aktivnosti za poticanje čitanja (Nacionalni kviz za poticanje čitanja, Natjecanje u čitanju naglas, Moja prva knjiga) te sudjeluje u projektima Gradske knjižnice Ante Kovačića. Sudjeluje i u više školskih projekata.

\subsubsection{Knjižnica Osnovne škole Ivana Perkovca, Šenkovec}

Škola u Šenkovcu nastavlja rad prve škole u Laduču koja je započela s radom oko 1854. godine. ${ }^{32}$ Do 1902. škola nije imala zgradu, a nastava se odvijala u ku-

\footnotetext{
29 Osnovna škola Antuna Augustinčića Zaprešić: 1854. - 2004.: 150. obljetnica javne škole u Brdovcu: 100. obljetnica pučke škole u Zaprešiću: 50. obljetnica osmogodišnje škole u Zaprešiću / glavna urednica Ivanka Tomić. Zaprešić: OŠ Antuna Augustinčića, 2004. Str. 25.

30 Spomenica Pučke škole Zaprešić. // Zaprešićki godišnjak 14(2004), str. 70.

31 Spomenica Obće pučke škole u Pušći 1848 - 1914. // Zaprešićki godišnjak 6(1996), str. 121-122.

32 Laljak, S. Općina Brdovec. // Brdovečki zbornik 4(2005), str. 108.
} 
ćama imućnijih seljaka. Nastava u prvoj školskoj zgradi počela je 1903. godine. Knjižnica je počela s radom 1963. Na početku njezina djelovanja u njoj je radio jedan učitelj, a sada diplomirana knjižničarka.

2018. godine imala je 311 članova, 7560 jedinica građe i posudbu od 2160 jedinica građe. Građu knjižnica nabavlja kupnjom i darom, a financira se iz sredstava Ministarstva znanosti i obrazovanja i iz sredstava škole. Po zastupljenosti najviše je tiskanih knjiga (95\%), časopisa (4\%), a najmanje (1\%) audiograđe. Knjižnica ima zaštićeni fond starijih knjiga izdvojen u posebnu zbirku. Otvorena je za korisnike 30 sati tjedno. Knjižnični program Metelwin uveden je 2012. godine, a mrežnu stranicu ima u sklopu mrežne stranice škole. Knjižničarka provodi brojne programe: susrete s književnicima i glumcima, postavlja izložbe povodom obljetnica, radi s djecom koja imaju slobodan sat te provodi radionice, najčešće likovne. Knjižnica sudjeluje u projektima Gradske knjižnice Ante Kovačića te organizira posjete učenika osmih razreda toj knjižnici.

\subsubsection{Knjižnica Osnovne škole Jakovlje, Jakovlje}

Počeci školstva u jakovljanskom kraju sežu u 1842. godinu kada je nastojanjem župnika s radom započela škola u Kraljevom Vrhu. 30-ih godina prošlog stoljeća izgrađene su škole u Igrišću i Kapelšćaku. Škola u Jakovlju osnovana je 1903. godine, od 1956. do 1973. bila je smještena u dvorcu Oršić Sixta, a 1973. godine sagrađena je današnja školska zgrada. ${ }^{33} \mathrm{U}$ školskoj godini 1963./64. kompletirana je knjižnica za nastavnike s priručnicima i udžbenicima. ${ }^{34} \mathrm{~S}$ vremenom se knjižnica razvija i upotpunjuje građom za učenike.

U knjižnici 2018. radi diplomirana knjižničarka. Knjižnica ima 350 članova, fond od 4500 jedinica građe te posudbu od 1615 jedinica građe. Građa se nabavlja kupnjom iz sredstava Ministarstva znanosti i obrazovanja i Zagrebačke županije te od zakasnina, a dio dobiva darom. Prema vrstama građe $90 \%$ je knjiga, a $10 \%$ ostale građe. Knjižnica ima posebnu zbirku posvećenu Domovinskom ratu. Održava programe knjižnično-informacijske pismenosti, okuplja grupu Mladi knjižničari, a knjižničarka uređuje školski časopis Jakov. Sudjeluje u projektima Gradske knjižnice Ante Kovačića i dio je nacionalnog projekta Čitamo mi, u obitelji svi. Knjižnica je otvorena za korisnike 30 sati tjedno, a za rad rabi program Metelwin. Ima mrežnu stranicu u sklopu mrežne stranice škole.

\subsubsection{Knjižnica Osnovne škole Ivane Brlić-Mažuranić, Prigorje Brdovečko}

Počeci osnovnog školstva u Prigorju Brdovečkom vežu se uz ranije spomenutu školu u Laduču. ${ }^{35}$ Osnovna škola u Prigorju Brdovečkom osnovana je 1946.

\footnotetext{
33 O školi. // Osnovna škola Jakovlje. [citirano 2020-05-29]. Dostupno na: http://os-jakovlje. skole.hr/naslovnica/o_koli/pov

34 Arhiva Osnovne škole Jakovlje. Spomenica škole Jakovlje. [interni dokument]

35 Vidi bilješke 17, 18 i 19.
} 
godine $^{36}$, a knjižnica je vjerojatno otvorena premještajem škole u novu školsku zgradu $^{37} 1966$. godine. ${ }^{38} \mathrm{U}$ prosincu 1984. u požaru su uništene knjižnica i knjižnična dokumentacija pa se pristupilo obnovi. Nova knjižnica otvorena je u travnju 1985. godine. ${ }^{39}$

U knjižnici 2018. radi jedna diplomirana knjižničarka. Iste je godine knjižnica imala 308 članova, fond od 4312 jedinice građe te posudbu od 1068 jedinica građe. Knjižnica građu nabavlja putem kupnje i darova, a financira se iz proračuna škole i Ministarstva znanosti i obrazovanja. Knjižnični fond sadrži tiskane knjige, časopise, sitni tisak, AVE-građu i društvene igre. Ima zavičajnu zbirku koja sadrži 280 knjiga i 40 jedinica sitnog tiska. Za korisnike je otvorena 30 sati tjedno, a za poslovanje rabi knjižničarski program Metelwin. Knjižnica ima mrežnu stranicu u sklopu mrežne stranice škole. Sudjeluje u programima i događanjima: Projekt straničnik, Književni susret te održava pričaonice za najmlađe, knjižnični odgoj i obrazovanje te aktivnosti na temu digitalne pismenosti i cyberbullyinga. Sudjeluje u projektima Gradske knjižnice Ante Kovačića te u Nacionalnom kvizu za poticanje čitanja.

\subsubsection{Knjižnica Osnovne škole Ante Kovačića, Marija Gorica}

Veliku ulogu u kulturnom, obrazovnom i odgojnom životu Marije Gorice ima škola osnovana 1854. godine. ${ }^{40}$ Današnja školska zgrada izgrađena je 1924. godine. Od 1997. bila je područna škola OŠ Ivane Brlić-Mažuranić iz Prigorja Brdovečkog, a 2007. se osamostaljuje. Prvi primjerak građe upisan je u inventarnu knjigu knjižnice 1968. godine.

U knjižnici 2018. radi diplomirana knjižničarka na pola radnog vremena. Knjižnica ima 130 članova i fond od 4603 jedinice građe. Građa se nabavlja kupnjom i darom. Financira se iz sredstava Ministarstva znanosti i obrazovanja, Zagrebačke županije, Općine Marija Gorica te iz proračuna škole. Fond čine: knjige (95\%), časopisi $(2 \%)$, novine $(0,5 \%)$, AVE-građa $(2 \%)$ i igračke $(0,5 \%)$. Za korisnike je otvorena 20 sati tjedno. Od školske godine 2019./2020. planirano je uvođenje programa Metelwin. Ima mrežnu stranicu u sklopu školske mrežne stranice te Facebook-stranicu u sklopu službene školske Facebook-stranice. Knjižničarka prati kulturno-javni plan i program škole u smislu obilježavanja važnih datuma i obljetnica, provodi programe za poticanje čitanja, surađuje s učiteljima, organizira satove lektire, sudjeluje u projektima i organizira radionice s učenicima. Jedna je od urednica školskog lista te administratorica mrežne i Facebook-stranice škole.

\footnotetext{
36 Općina Brdovec / glavna urednica Snježana Zrinjan. Brdovec: Općina Brdovec, 2017. Str. 193.

37 Crtice iz povijesti školske knjižnice. // Osnovna škola Ivane Brlić-Mažuranić Prigorje Brdovečko. [citirano: 2020-03-22]. Dostupno na: http://www.os-ibmazuranic-prigorjebrdovecko. skole.hr/skola/knjiznica/o_knji_nici.

38 Općina Brdovec. Nav. dj, str. 199.

39 Crtice. Nav. dj.

40 Arhiva Osnovne škole Ante Kovačića. Uspomenica učione Maria Gorica. [interni dokument]
} 
Knjižnica sudjeluje u projektima poticanja čitanja: Čitamo mi, u obitelji svi i Riječ dana te u projektima Gradske knjižnice Ante Kovačića. Surađuje i s Općinom Marija Gorica u programima Obiteljski proljetni izazov i Ljeto u Mariji Gorici te na međunarodnoj razini u projektu razmjene straničnika.

\subsubsection{Knjižnica Osnovne škole Ljudevita Gaja, Zaprešić}

Knjižnica Osnovne škole Ljudevita Gaja otvorena je kada i škola, 1980. godine. ${ }^{41}$ Tada je u knjižnici radio jedan knjižničar, a 2018. radi diplomirana knjižničarka na puno radno vrijeme. Po osnutku je knjižnica imala 865 članova, a 2018. ima 921.

Fond se sastoji od 9549 jedinica građe, a posuđeno je 4366 jedinica građe. Nabava se vrši darom i kupnjom koja se financira iz sredstava škole i Ministarstva znanosti i obrazovanja. Knjižnica ima najviše tiskanih knjiga (80 \%), slijede časopisi $(10 \%)$, novine (5\%) te AVE-građa (5\%). Otvorena je za korisnike 30 sati tjedno. Od 2010. godine posluje pomoću programa Metelwin. Ima mrežnu stranicu u sklopu stranice škole. Knjižničarka okuplja djecu u Mlade knjižničare te od programa posebno ističe neposredan rad s učenicima po kurikulumu i temama, obradu lektire, susrete s književnicima te sudjelovanje u kvizovima za poticanje čitanja. Knjižnica sudjeluje u projektu poticanja čitanja Čitajmo zajedno. Na lokalnoj razini sudjeluje u projektima Gradske knjižnice Ante Kovačića te na nacionalnoj razini u Nacionalnom kvizu za poticanje čitanja.

\subsubsection{Knjižnica Osnovne škole Kupljenovo, Kupljenovo}

1912. godine u Kupljenovu je otvorena prva škola. Od 1980. do 1990. godine djeluje kao područna škola tadašnje OŠ Sjever (danas OŠ Ljudevita Gaja). Škola se osamostaljuje 1990. godine ${ }^{42}$, kada s radom počinje i školska knjižnica. Od osnutka u knjižnici radi jedna osoba na pola radnog vremena. Ranije su to bili nastavnik glazbene kulture i učitelj razredne nastave, a u trenutku istraživanja diplomirana knjižničarka. Knjižnica je 1990. imala 250, a 2018. 152 člana. Početni fond knjižnice bio je 500 jedinica građe, a 2018. 2199. Zbog radova i selidbe nema zabilježenu posudbu u 2018. godini, kao ni podatke o zastupljenosti vrsta građe. Knjižnica je otvorena za korisnike 20 sati tjedno. Građu nabavlja isključivo kupnjom koju financira iz sredstava Ministarstva znanosti i obrazovanja te Grada Zaprešića. Provodi radionice i projekte u suradnji s gradišćanskim Hrvatima s ciljem očuvanja hrvatskog jezika, kulture i tradicije te programe za poticanje čitanja u suradnji s učiteljima razredne nastave. Surađuje sa susjednim školskim knjižnicama i Gradskom knjižnicom Ante Kovačića. 2009. godine uveden je u rad program Metelwin. Knjižnica je zastupljena na mrežnim stranicama škole.

41 Zaprešić: monografija / glavna urednica Višnja Goljački. Nav. dj., str. 229.

42 Isto. 


\subsubsection{Knjižnica Srednje škole Ban Josip Jelačić, Zaprešić}

Srednja škola Ban Josip Jelačić u Zaprešiću jedina je srednja škola na području Zaprešića i okolice. Školska knjižnica otvorena je, kao i škola, 2003. godine. ${ }^{43}$ Od osnutka u knjižnici radi diplomirani knjižničar na puno radno vrijeme. Fond knjižnice u prvoj godini rada iznosio je oko 500 jedinica građe, a 2018. oko 6300, s posudbom od 1214 jedinica građe. Knjižnica je iste godine imala 806 članova. Građu nabavlja kupnjom sredstvima Ministarstva znanosti i obrazovanja i iz sredstava škole te darom. Knjižnični fond čini $80 \%$ knjiga, $15 \%$ časopisa i $5 \%$ ostale građe (sitnog tiska i AVE-građe).

Tjedno je knjižnica otvorena za korisnike 30 sati, a djelatnica za rad rabi program Metelwin. Mrežna stranica knjižnice dio je mrežne stranice škole. Knjižnica aktivno sudjeluje u radu škole organizacijom izložbi, književnih večeri, radionica, kroz projektnu nastavu, obilježavanjem raznih događaja te je uključena u nastavu pojedinih predmeta. U galeriji knjižnice održavaju se izložbe, skupovi, koncerti i plesovi. Knjižnica surađuje s novinarskom skupinom u izdavanju školskog časopisa Ban, sa školskom zadrugom Ban, s Gradskom knjižnicom Ante Kovačića te sudjeluje u brojnim školskim i međunarodnim projektima: Erasmus ${ }^{+}$, E-twinning, DSD-program i SHE-projekt.

\subsection{Narodne knjižnice}

Na temelju proučene literature može se zaključiti da se narodne čitaonice i knjižnice na zaprešićkom području osnivaju krajem 19. i u prvoj polovici 20. stoljeća. Te su čitaonice i knjižnice bile osnivane uglavnom zalaganjem naobraženih pojedinaca entuzijasta ili u okviru prosvjetno-glazbenih društava koja su imala veliku ulogu u poticanju prosvjetno-kulturnog života toga doba. Rad prvih čitaonica i knjižnica prekida Drugi svjetski rat 1941. godine nakon kojega se u većini mjesta zaprešićkog kraja osnivaju nove knjižnice amaterskog karaktera. Nakon rata raste svijest o nužnosti obrazovanja i pismenosti te se u tom zamahu otvaraju brojne narodne knjižnice i čitaonice, kako piše Stipanov ${ }^{44}$, ne samo na razini općina, gradova i poduzeća već i na razini ulice ili neke zgrade, ali se zbog nedostatka stručnih kadrova i kontinuiranog financiranja većina njih ubrzo zatvorila. Prikupljanje knjiga za poslijeratne knjižnice u Zaprešiću i okolici organizira mladež, često uz pomoć starijih članova Narodnog fronta. Rad je bio dobrovoljan i amaterski, stoga su te knjižnice ubrzo prestale djelovati. ${ }^{45}$

1960. donesen je prvi zakon o knjižnicama i knjižničarstvu u Hrvatskoje koji je postavio pravno-stručni okvir za djelovanje svih vrsta knjižnica. Za dalj-

43 Isto, str. 230.

44 Stipanov, J. Nav. dj., str. 223-224.

45 Narodno sveučilište Zaprešić: 1958 - 1968. Zaprešić: Narodno sveučilište, 1968. Str. 12.

46 Zakon o bibliotekama. // Vjesnik bibliotekara Hrvatske 6, 3/4(1960), str. 75-81. 
nji razvitak narodnih knjižnica i profesionalizaciju struke od velike su važnosti i standardi za narodne knjižnice doneseni 70-ih godina. Narodne se knjižnice više-manje uspješno razvijaju i profesionaliziraju, a nakon Zakona o knjižnicama iz 1997. prema Stipanovu sve su se više profilirale i potvrdile kao istinska kulturno-informacijska središta lokalnih sredina, šireći usluge u skladu s prepoznatim potrebama korisnika, služeći se suvremenom informacijskom i komunikacijskom tehnologijom. ${ }^{47}$

\subsubsection{Počeci narodnog knjižničarstva u Zaprešiću i okolici}

Knjižnična djelatnost u Zaprešiću započela je 1896. godine kada Ivan Ivančić pokreće osnivanje prve zaprešićke čitaonice. ${ }^{48}$ Čitaonica je imala svoja pravila koja je odobrila Zemaljska vlada 15. rujna 1896. godine te vlastiti žig ${ }^{49}$. Imala je veliku ulogu u tadašnjem kulturnom i obrazovnom životu Zaprešića jer u doba njezina osnivanja nije postojala ni pučka škola ni bilo koja druga kulturno-obrazovna ustanova. ${ }^{50} \mathrm{U}$ trenutku osnivanja imala je 35 članova iz Zaprešića i okolice. ${ }^{51}$ U Pravilima društva „Čitaonice” u Zaprešiću navedeno je da joj je svrha međusobno usavršavanje, promicanje književnosti i socijalnih odnosa te da Čitaonica u tu svrhu nabavlja novine, časopise i periodične listove te organizira sve pristojne nezabranjene igre, društvene plesove, večernje zabave, tombole itd. Članom je mogao postati svatko, bez razlike u spolu. Bila je otvorena od 8 sati sve dok se članovi u njemu budu nalazili i dok policijski red to dopušta. ${ }^{52}$ Plaćala se mjesečna članarina. ${ }^{53}$ Čitaonica je djelovala do smrti njezina osnivača 1909. godine. ${ }^{54}$

Prva Čitaonica i knjižnica u Brdovcu djelovala je od 1921. do 1941. ${ }^{55}$ Osnovalo ju je Prosvjetno-glazbeno društvo „Kačić” (utemeljeno oko 1918.) čiji su ju članovi odbora dobrovoljno vodili. Bila je smještena u privatnoj kući i imala je knjižnični fond od 300 knjiga. ${ }^{56}$ Od 1931. (prema nekim izvorima 1933.) do 1941. djelovala je Narodna knjižnica i čitaonica u Prudnicama, osnovana na inicijativu Jože Gregorina i nekoliko mještana. ${ }^{57} \mathrm{U}$ sačuvanim pravilima knjižnice nave-

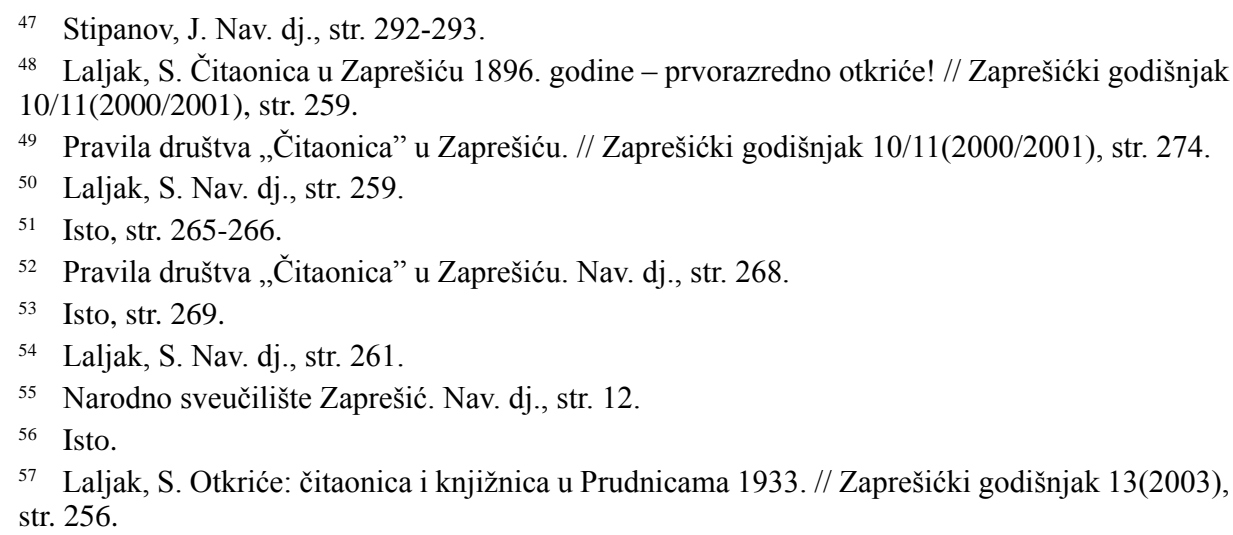


deno je da ima svrhu „brinuti se za svestranu izobrazbu svojih članova, krijepiti među njima narodnu svijest i ljubav k jedinstvu države te širiti prosvjetu medju narodom. “" ${ }^{58}$ To će se postići tako da društvo

„,ima svoje prostorije s vlastitom knjižnicom i čitaonicom za članstvo i javnost, da širi časopise i druge publikacije, da priredjuje sastanke, razgovore, poučna predavanja, skupne izlete i druge poučne tečajeve, da skrbi za priredbe s predstavama i zabavama. " 59

Knjižnica je u svom sastavu imala i kazališnu družinu i pjevački zbor. Čitaonica je bila pretplaćena na dnevni tisak i nekoliko časopisa. Održavana su predavanja iz kulture, znanosti i politike. Postoje zapisi o knjižničnom fondu s 500 svezaka koji je rabilo 200 članova. Knjižnica je proširila svoj rad i na susjedna mjesta, uključivala se u politička zbivanja i sudjelovala u demonstracijama. ${ }^{60}$

Od 1934. do 1941. godine u Zaprešiću je djelovala Sindikalna čitaonica Tvornice suhomesnate robe. Raspolagala je pretežno političkim tiskom i literaturom. Njezin rad prekinuo je rat 1941. godine. ${ }^{61}$

U Savskom Marofu 1936. godine osnovano je Hrvatsko prosvjetno-glazbeno društvo „Tomislav“ koje je imalo važnu ulogu u kulturnom životu toga doba u brdovečkom kraju. Osnivači društva bili su domaći ljudi, namještenici Tvornice žeste i pjenice u Savskom Marofu. ${ }^{62} \mathrm{U}$ pravilima društva istaknuto je da je zadatak društva da među narodom širi prosvjetu u pravcu kulturnog, ekonomskog i socijalnog podizanja, a među sredstvima kojima će društvo to postići istaknuto je da će nabavljati dobre i poučne knjige te ih davati među članove na čitanje, u koju će svrhu osnovati društvenu knjižnicu. ${ }^{63}$ Osim pravila još su sačuvani pečat i neke članske iskaznice i knjige iz knjižnice tog društva. Nema zapisa o točnoj godini prestanka rada društva i knjižnice, pretpostavlja se da je prestala djelovati početkom Drugog svjetskog rata. ${ }^{64}$

Narodna knjižnica Brdovec osnovana je 1950. godine ${ }^{65}$ te je bila smještena u Zadružnom domu u Brdovcu. Inicijativa za osnivanjem knjižnice postojala je nekoliko godina ranije kada su mještani skupili knjige iz fonda prve Čitaonice

\footnotetext{
58 Pravila Narodne knjižnice i čitaonice u Prudnicama Općine Brdovec. // Zaprešićki godišnjak 13(2003), str. 262.

59 Isto.

60 Arhiva Gradske knjižnice Ante Kovačića. Narodna čitaonica i knjižnica u Prudnicama. [interni dokument]

61 Laljak, S. Nav. dj., str. 262.

62 Laljak, S. Kulturno-prosvjetni amaterizam i društvo „Tomislav” 1936. // Brdovečki zbornik 2(2003), str. 129.

63 Pravila Hrvatskog prosvjetnog i glazbenog društva „Tomislav” u Savskom Marofu. // Brdovečki zbornik 2(2003), str. 131.

64 Laljak, S. Kulturno-prosvjetni amaterizam. Nav. dj., str. 129.

65 Arhiva Gradske knjižnice Ante Kovačića. Narodna knjižnica Brdovec. [interni dokument]
} 
i knjižnice u Brdovcu i knjige iz nacionalizirane imovine obitelji Janeković. No zbog nedostatka prostora knjige su 1947. godine smještene u prostorije Radne zadruge Brdovec u dvorcu Lužnica te je osnovana knjižnica zadrugara. Knjižnični je fond povećan, no knjige nisu bile odgovarajuće smještene, nije bilo stručnog knjižničara te su mnoge uništene. Kada se 1950. rasformirala Radna zadruga Brdovec, knjige su premještene u Zadružni dom u Brdovcu gdje je osnovana Narodna knjižnica Brdovec. 1964. ona potpada pod djelokrug Općinske knjižnice Zaprešić i postaje prvotno njezinom knjižnom stanicom, a zatim područnom knjižnicom. ${ }^{66} \mathrm{~S}$ radom je prestala 1995. te je njezin fond pohranjen na čuvanje u Gradsku knjižnicu Ante Kovačića u Zaprešiću sve do 2018. kada je vraćen u Brdovec i čeka ponovno otvorenje knjižnice.

Od 1965. do 1978. djelovala je Narodna knjižnica u Prigorju Brdovečkom, prvotno kao knjižnična stanica, a zatim područna knjižnica Općinske knjižnice Zaprešić. ${ }^{67}$

U sastavu tvornice Jugokeramika u Zaprešiću (od 1991. Inker) od pedesetih do devedesetih godina 20. st. djelovala je Sindikalna biblioteka Jugokeramike. ${ }^{68}$ Imala je karakteristike specijalne i narodne knjižnice jer su njezin fond činile stručna literatura (knjige i časopisi) iz područja keramike i beletristika. ${ }^{69} \mathrm{Knjiž-}$ nica je imala zaposlenog profesionalnog knjižničara, posudba za radnike bila je besplatna, a korisnici su mogli naručiti pojedine naslove iz Općinske knjižnice Zaprešić. ${ }^{70}$ Jedan od knjižničara u periodu od 1963. do 1978. bio je Dragutin Balagović koji je, uz uobičajene knjižničarske poslove, s engleskog i njemačkog prevodio stručne članke i knjige iz područja keramike. ${ }^{71}$

Na području Zaprešića i okolice knjižničnu djelatnost već desetljećima obavlja i Bibliobusna služba Knjižnica grada Zagreba koja djeluje od 1976. godine ${ }^{72}$, a već od 1978. dolazi u naselja Zaprešića i okolice: Mariju Goricu, Trstenik i Prigorje Brdovečko, od 1981. u Pojatno, Pušću i Dubravicu, a od 1991. u Kupljenovo i Jablanovec. Između 2000. i 2003. bibliobus počinje dolaziti u Luku, a između 2006. i 2009. u Brdovec, Šenkovec, Jakovlje i Drenje. ${ }^{73}$ U trenutku istraživanja obilazi ukupno 13 stanica u okolici Zaprešića. Dolazi još u naselje Laduč te u Dom

\footnotetext{
66 Isto.

67 Narodno sveučilište Zaprešić. Nav. dj., str. 13.

68 Prema kazivanju Zdenke Kamčev, nekadašnje djelatnice tvornice Jugokeramika. [7.4.2020.]

69 Isto.

70 Leško, N. Knjiga u radnim kolektivima. // Zaprešićke novine: glasilo Socijalističkog saveza naroda općine Zaprešić 2, 7(1980), str. 7.

71 Laljak, S. Dragutin Balagović (1933 - 1997). // Zaprešićki godišnjak 7(1997), str. 350.

72 Knjižnica u pokretu: 40 godina zagrebačke bibliobusne službe / priredila Đurđica Pugelnik. Zagreb: Knjižnice grada Zagreba, 2016. [citirano: 2020-02-06]. Dostupno na: https://digitalnezbirke.kgz.hr/?object=view\&id=18971.

73 Isto.
} 
za starije i nemoćne Zlatno doba u Pušći, a prestao je dolaziti u Mariju Goricu zbog osnivanja općinske narodne knjižnice 2017. godine.

\subsubsection{Općinska knjižnica Bistra}

U bistranskom kraju u prošlosti su djelovale dvije narodne knjižnice i čitaonice: u Donjoj Bistri (otvorena 1946.) i u Poljanici Bistranskoj (otvorena 1947.). ${ }^{74}$ Za knjižnicu i čitaonicu u Donjoj Bistri nema podataka kada je zatvorena, dok knjižnica i čitaonica u Poljanici Bistranskoj ima svojevrstan kontinuitet sve do danas. Ta je knjižnica od 1958. djelovala kao područna knjižnica Općinske knjižnice Zaprešicic ${ }^{75}$, a nakon njezina zatvaranja 1993. cjelokupan je fond pohranjen u zasebno spremište u Gradskoj knjižnici Ante Kovačića u Zaprešiću gdje je ostao do ponovnog otvorenja knjižnice. ${ }^{76}$

Današnja Općinska knjižnica Bistra u Poljanici Bistranskoj ponovno je osnovana $2004 .{ }^{77}$ kao samostalna ustanova te je za korisnike otvorena u prosincu 2007. ${ }^{78}$ Smještena je u zgradi Kulturnog centra Bistra u suvremeno opremljenom prostoru od $140 \mathrm{~m}^{2} \mathrm{~s}$ mogućnošću uporabe dvorane za kulturno-animacijske priredbe. Prostor je podijeljen na Odjel za odrasle s čitaonicom i Dječji odjel. U knjižnici je zaposlena jedna diplomirana knjižničarka. Knjižnični fond izgrađen je na temeljima fonda stare knjižnice i činila ga je 4321 jedinica građe. Godine 2008. u fondu je bilo 6802, a 2018. 22545 jedinica građe, od čega 89 \% knjižne i $11 \%$ AVE-građe. Dio fonda organiziran je kao Zaštićeni fond koji čine starija građa i zavičajna zbirka. Knjižnica građu nabavlja darom i kupnjom sredstvima Ministarstva kulture, Općine Bistra, Zagrebačke županije te vlastitim sredstvima. 2008. knjižnica je imala 297 članova koji su posudili 6048 jedinica građe, a 2018. 672 člana koji su posudili 14694 jedinice građe. U knjižnici se održavaju predstavljanja knjiga, izložbe, predavanja, kreativne radionice i projekti namijenjeni različitim skupinama korisnika, ponajviše umirovljenicima i djeci. Kreativnim radionicama potiču se čitanje i pisanje priča. Knjižnica rabi računalni program Zaki od 2007. Nema mrežnu, ali ima Facebook-stranicu. 2018. godine otvorena je za korisnike 25 sati tjedno.

\footnotetext{
74 Školska spomenica od škole bistranske, i njezinoga početka. // Zaprešićki godišnjak 17(2007), str. 297.

75 Bistra: monografija. Nav. dj., str. 121.

76 Arhiva Gradske knjižnice Ante Kovačića. Zapisnik o postupku s knjigama Područne knjižnice Bistra. [interni dokument]

77 Odluka o osnivanju javne ustanove Općinska knjižnica Bistra. // Službeni glasnik Općine Bistra 24(2004), str. 15.

78 Općinska knjižnica i čitaonica Bistra. // Knjižnica.hr. [citirano: 2020-05-28]. Dostupno na: https://www.knjiznica.hr/knjiznice/?id=305.
} 


\subsubsection{Gradska knjižnica Ante Kovačića, Zaprešić}

Gradska knjižnica Ante Kovačića iz Zaprešića (u daljnjem tekstu: GKAK) osnovana je u studenom 1958. godine pod nazivom Općinska knjižnica Zaprešić kao samostalna ustanova u prostoru tadašnjeg Narodnog sveučilišta Zaprešić. Godine 1966. integrirana je s Narodnim sveučilištem ${ }^{79}$, a od 1986. djeluje u sadašnjem prostoru i pod sadašnjim nazivom te postaje dio Knjižnica grada Zagreba. ${ }^{80}$ Skupština Općine Zaprešić donijela je odluku da knjižnica u Zaprešiću od 1. siječnja 1964. djeluje kao samostalna ustanova na području cijele Općine Zaprešić kao matična knjižnica i radi na širenju i propagiranju knjige: vodi mjesnu knjižnicu i čitaonicu u Zaprešiću; formira knjižnične stanice, stacionare i samoposudbene ormariće; osniva nove knjižnice; vodi brigu o svim postojećim knjižnicama i pruža im stručnu pomoć. ${ }^{81}$ Od šezdesetih do devedesetih godina 20. st. mrežu knjižnica zaprešićkog područja čine: Općinska knjižnica Zaprešić (s funkcijom matične knjižnice), Područna knjižnica Bistra (osnovana 1947., prestala s radom 1993.; od 1958. do 1993. ogranak GKAK-a), Područna knjižnica Brdovec (osnovana 1950., prestala s radom 1995.; od 1964. do 1995. ogranak GKAK-a) i Područna knjižnica Prigorje Brdovečko (osnovana 1965., prestala s radom 1978.; bila ogranak GKAK-a). Pored tradicionalnih knjižnica, specifičnost sedamdesetih i osamdesetih 20. st. intenzivna je suradnja zaprešićke matične knjižnice sa sindikalnim organizacijama pojedinih radnih organizacija na području tadašnje Općine Zaprešić na način da su se u radnim organizacijama osnivale knjižnične stanice, stacionari i ormarići za samoposudbu knjiga. Brigu o nabavi, stručnoj obradi te redovitoj dostavi i izmjeni knjiga (najčešće svaka dva tjedna) vodili su zaposlenici Općinske knjižnice Zaprešić prilagođavajući oblik posudbe broju zaposlenih u radnoj organizaciji i interesu za knjige. Pritom su radne organizacije novčanim sredstvima sudjelovale u nabavi knjiga, a knjižnica je besplatno upisivala nove članove. Prema istraživanju provedenom $u$ to doba ${ }^{82}$, takav način posudbe knjiga bio je jako popularan među radnicima zato što su im knjige bile skupe za kupovinu, a nekima od njih knjižnice preudaljene ili nedostupne. Osim posudbom knjiga popularizacija knjige i čitanja u radnim organizacijama provodila se i organizacijom književnih susreta i drugih kulturnih događanja te uređivanjem posebnih panoa s omotima novih izdanja. Prema sačuvanim podacima za 1985. godinu ${ }^{83}$ knjižnične stanice, stacionari i samoposudbeni ormarići bili su u funkciji u radnim organizacijama: Karbonu, Montkemiji, Lancu i Kogrozu u Zaprešiću; Plivi u Savskom Marofu, Strojaru u Bistri i VP-u Brdovec. Navedene vrste ustrojbenih jedinica bile su osnovane i u Bolnici za kronične dječje bolesti u Bistri, Dječjem domu Laduč, mjesnoj zajednici „Bratstvo i jedinstvo - Sjever” te nekim selima (Drenju, Ladu-

79 Narodno sveučilište Zaprešić. Nav. dj., str. 13.

80 Zaprešić: monografija. Nav. dj., str. 199.

81 Narodno sveučilište Zaprešić. Nav. dj., str. 13.

82 Leško, N. Nav. dj., str. 7.

83 Arhiva Gradske knjižnice Ante Kovačića. Knjižni stacionari 1984./1985. [interni dokument] 
ču, Pojatnom, Hruševcu Kupljenskom) i osnovnim školama u okolici. Područne knjižnice, knjižnične stanice i stacionari s radom prestaju krajem osamdesetih i početkom devedesetih godina ponajviše zbog uvođenja sve većeg broja stanica Bibliobusne službe Knjižnica grada Zagreba.

Početni fond Općinske knjižnice Zaprešić 1958. godine iznosio je 1560 knjiga. Na kraju 1959. godine iznosio je 1666 knjiga te su upisana 272 člana koji su pročitali 2849 knjiga. 1959. godine knjižnica je tjedno bila otvorena 5 sati. $^{84}$ Deset godina od osnutka (1968.) knjižnica ima vlastitu prostoriju za rad od 120 m², 2 zaposlena knjižničara, 9297 svezaka knjiga u knjižnici u Zaprešiću, 1045 u knjižnoj stanici Brdovec i 1865 u knjižnoj stanici Prigorje Brdovečko. Knjižnica u Zaprešiću ima 538 članova, a putujuće knjižnice 500 članova. Knjižnična stanica u Brdovcu ima 90, a Prigorje Brdovečko 154 člana. Usporedno s porastom broja knjiga i članova povećan je i broj sati otvorenosti za korisnike s 5 na 39 sati rada tjedno. Knjižnica je za korisnike bila otvorena radnim danima poslijepodne i subotom prijepodne. Čitaonica postoji samo u Zaprešiću i prosječno ju posjećuje 50 čitatelja dnevno. U tom razdoblju knjižnica je organizirala razna događanja: izložbe knjiga, susrete s književnicima, večeri pjesama, predavanja, projekcije filmova i predstavljanje knjižnice na Cvjetnom korzu s propagandnim materijalima. ${ }^{85}$

U vrijeme istraživanja Gradska knjižnica Ante Kovačića suvremena je i moderna institucija koja ide ukorak s društvenim i tehnološkim promjenama. U prostor knjižnice od $870 \mathrm{~m}^{2}$ smješteni su Čitaonica, Odjel za odrasle, Odjel za djecu, Odjel za mladež, AVE-odjel, Zavičajna zbirka te Služba nabave i obrade građe. Zaposleno je 18 djelatnika: 10 diplomiranih knjižničara, 6 pomoćnih knjižničara, 1 knjižnični manipulant i spremačica. Poslovanje knjižnice odvija se pomoću računalnog programa Zaki koji je uveden 2001. godine. Knjižnica se javnosti predstavlja putem mrežne stranice u sklopu mrežne stranice KGZ-a, Facebook-stranice te lokalnih medija. Tjedno je otvorena 66 sati za korisnike. 2018. imala je 6545 članova i fond od 104005 jedinica građe, od čega knjižne 93 892, a neknjižne (AVE-građe, igračaka, notne građe, grafičke građe, novina i časopisa) 10113 jedinica. 2018. članovi su posudili 101232 knjižne i 11542 jedinice neknjižne građe. ${ }^{86}$ Građa se nabavlja kupnjom sredstvima Grada Zaprešića, Ministarstva kulture i Zagrebačke županije te vlastitim izdanjima i darom. Knjižnica ima tri posebne zbirke: Zaštićeni fond, Zavičajnu zbirku (od 1982.) i Igroteku (od 1989.) te tri kutka izdvojene građe: Kutak za roditelje, Građu laganu za čitanje i Makedonski kutak. Iz godišnjih izvještaja o radu knjižnice vidljivo je kako knjižnica organizira brojna predstavljanja knjiga, predavanja, radionice, predstave, koncerte i povremeno okrugle stolove i stručne skupove. Dnevno knjižnicu posjećuje velik broj odraslih i djece

\footnotetext{
${ }^{84}$ Narodno sveučilište Zaprešić. Nav. dj., str. 13.

85 Isto, str. 14.

86 Arhiva Gradske knjižnice Ante Kovačića. Izvještaj Gradske knjižnice Ante Kovačića za 2018. godinu. [interni dokument]
} 
koji se u prostoru knjižnice zadržavaju kraće (povrat i posudba građe, kratke informacije) ili duže (u Čitaonici dnevnog tiska i časopisa, na računalima za korisnike, Playstationu, studijskoj čitaonici, radi pisanja zadaće i druženja). Osobito potiče čitanje i boravak u knjižnici za najmlađe kroz vlastite programe i projekte: Pričaonica, Bake i djedovi pričaju priče, Lektira u knjižnici, Kreativna radionica, Radionica talijanske kulture, Glazbeni vrtić i Knjižnica u gostima te brine o najstarijim članovima provođenjem programa za umirovljenike u sklopu projekta 65 plus KGZ-a: Parliamo italiano, Kreativna radionica, Kutak za umirovljenički trenutak, Sat informatičke pismenosti, Mala škola mobitela, Vježbanje i Joga. Među odraslim članovima osobito je popularan Čitateljski klub koji kontinuirano djeluje od 2014. Knjižnica razvija i vlastite projekte u kojima surađuje sa školama i školskim knjižnicama Zaprešića i okolice te radi na očuvanju zaprešićke kulturne baštine: Poetski susreti djece Zaprešića (od 1970.), Wiki-dveri (2009. - 2018.), Naslikajmo priču (od 2016.), Planinarski tjedan (od 2017.), Zaprešić u prošlosti (od 2019.), Upoznaj svoju baštinu! - kviz za učenike osnovnih škola zaprešićkog kraja (od 2019.) i Zgubidan - dani digitalnog stvaralaštva djece Zaprešića (od 2019.). Sudjeluje i u projektima drugih ustanova: Pitajte knjižničara, Zelena knjižnica, I ja želim čitati, Microbit, Kovačić Ante - neka te učenici pamte! Ima razvijenu izložbenu djelatnost kroz Veliku galeriju slika i Malu galeriju kreativnih radova. Provodi projekt digitalizacije starih razglednica Zaprešića i okolice pod nazivom Digitalizirana zaprešićka baština te ima razvijenu nakladničku djelatnost u tiskanom i digitalnom obliku. U tiskanom obliku objavljuje zbornike radova Poetskih susreta djece Zaprešića od 2005. godine (15 naslova). Digitalna izdanja objavljuje od 2017. u okviru projekta Digitalna zbirka Zaprešića koja je pohranjena na portalu Digitalne zbirke Knjižnica grada Zagreba. Kroz tri nakladnička niza dosada je objavljeno 13 djela lokalnih autora, odraslih i djece, te djela o Zaprešiću i okolici.

Iako već dugo formalno nije matična (središnja) knjižnica zaprešićkog područja, Gradska knjižnica Ante Kovačića brojnim projektima i programima okuplja ostale knjižnice i knjižničare Zaprešića i okolice, bez obzira na vrstu.

\subsubsection{Općinska knjižnica Ante Kovačića, Marija Gorica}

Općinska knjižnica Ante Kovačića u Mariji Gorici osnovana je 2017. ${ }^{87}$ u zgradi s primjerenim uvjetima i prostorom za rad u kojem se nalaze Dječji odjel, Odjel za odrasle s čitaonicom, opremljenom novim računalima, i galerijski prostor. Rabi računalni program Zaki te se korisnicima predstavlja putem Facebook-stranice i mrežne stranice Općine Marija Gorica. Otvorena je za korisnike 26 sati tjedno. Fond čine tiskane knjige, novine, časopisi, AVE-građa, igračke i društvene igre. Građa se nabavlja kupnjom sredstvima Općine Marija Gorica, Ministarstva kultu-

${ }^{87}$ Odluka o osnivanju javne ustanove - Općinske knjižnice Marija Gorica. // Službeni glasnik Općine Marija Gorica 177(2017). [citirano: 2020-05-22]. Dostupno na: https://marija-gorica.hr/ images/dokumenti/sluzbeni-glasnik/2017/glasnik_177.pdf 
re i Zagrebačke županije te darom. Početni knjižnični fond od 5000 jedinica građe u 2018. narastao je na 6530 jedinica građe. Od 2019. knjižnica ima Zavičajnu zbirku sa 125 jedinica građe, a dio građe Zavičajne zbirke planira se digitalizirati. 2017. knjižnica je imala 57, a 2018. 190 članova koji su 2017. posudili 151, a 2018. 1636 jedinica građe. Organizira brojna predavanja, predstavljanja knjiga i pisaca, predstave te program poticanja čitanja za djecu najmlađe dobi - ČitAJMO!. Knjižnica surađuje s Gradskom knjižnicom Ante Kovačića u Zaprešiću kroz razmjenu građe te Srednjom školom Ban Josip Jelačić iz Zaprešića, Općinskom knjižnicom Bistra i Knjižnicom Stubičke Toplice. Sudjeluje u manifestaciji Noć knjige, projektima Ljeto u Mariji Gorici i Kovačić Ante, neka te učenici pamte!. 2019. knjižnica je pokrenula vlastiti projekt međunarodne suradnje za pisce $U$ registraturi kojem je glavni cilj kroz kulturnu razmjenu potaknuti promociju Ante Kovačića i njegovih djela u međunarodnom kontekstu.

\subsection{Visokoškolska knjižnica}

Novi Zakon o knjižnicama i knjižničnoj djelatnosti ${ }^{88}$ prvi put razlikuje javne i privatne knjižnice. Javna je knjižnica neprofitna pravna osoba koja obavlja knjižničnu djelatnost sukladno Zakonu, kojoj je osnivač Republika Hrvatska, jedinice lokalne i područne (regionalne) samouprave, pravna osoba u pretežitom vlasništvu Republike Hrvatske ili jedinice lokalne i područne (regionalne) samouprave, odnosno zajedno s njima druga pravna i fizička osoba, dok je privatna knjižnica ona kojoj je osnivač druga pravna ili fizička osoba. Zaprešić nema dugu tradiciju visokog školstva, no u njemu od 2001. djeluje jedno privatno visoko učilište - Veleučilište Baltazar Zaprešić.

\subsubsection{Knjižnica Veleučilišta Baltazar Zaprešić}

Od rujna 2003. godine ${ }^{89} \mathrm{u}$ sastavu privatnog Veleučilišta Baltazar Zaprešić djeluje visokoškolska knjižnica. U listopadu 2011. knjižnica se preselila u nov, moderno opremljen prostor od $265,1 \mathrm{~m}^{2}$ u kojemu je korisnicima na raspolaganju 50 mjesta za rad i 10 računala sa slobodnim pristupom internetu. Članovi su knjižnice studenti, nastavno i nenastavno osoblje Veleučilišta, vanjski suradnici te bivši studenti (članovi Alumni kluba Veleučilišta). Studenti drugih visokih učilišta građom se mogu koristiti samo u čitaonici. Školske godine 2003./2004. knjižnica je imala 295 članova, a 2018. 2284. Za korisnike je otvorena 50 sati tjedno. Članovima je omogućena usluga međuknjižnične posudbe i usluga pripreme literature za pisanje radova..$^{90}$

88 Zakon o knjižnicama i knjižničnoj djelatnosti. // Narodne novine 17, 356(2019). [citirano: 2020-03-06]. Dostupno na: https://narodne-novine.nn.hr/clanci/sluzbeni/2019_02_17_356.html

89 Podatak prema prvom inventarnom broju upisanom u inventarnu knjigu knjižnice.

90 Knjižnica. // Veleučilište Baltazar Zaprešić. [citirano: 2020-06-17]. Dostupno na: https://www. bak.hr/hr/referada/knjiznica 
Do 2008. u knjižnici je radila jedna djelatnica, a u trenutku istraživanja zaposlene su dvije - diplomirana knjižničarka (voditeljica) i pomoćna knjižničarka. Početni fond sastojao se od 30 jedinica građe, a 2018. taj je broj dosegao 12525 jedinica građe. Podataka o posudbi u godini osnutka knjižnice nema. 2018. godine posuđena je 7601 jedinica građe. Građa se nabavlja kupnjom, darom, zamjenom i vlastitim izdanjima. Kupnju financira Veleučilište iz vlastitih sredstava. Prioritet u nabavi, prema Protokolu o nabavi knjižnične građe, ispitna je literatura, a zatim slijede stručna literatura za nastavno osoblje, literatura prema preporuci knjižničara te literatura koju može preporučiti nenastavno osoblje Veleučilišta. U fondu su zastupljene tiskane knjige (preko $90 \%$ ) te e-građa i časopisi. Raspoređen je na zbirke ispitne literature, referentne građe, vlastitih izdanja, inozemne literature, e-građe i završnih radova studenata Veleučilišta. U veljači 2019. knjižnica je oformila digitalni repozitorij završnih radova u sustavu Dabar u suradnji sa Sveučilišnim računskim centrom Srce. Time je ispunila svoju zakonsku obvezu, ali i dugogodišnju težnju veće dostupnosti završnih radova široj javnosti. S vremenom se u repozitoriju planiraju pohranjivati i radovi nastavnog osoblja te drugi digitalni sadržaji.

Knjižnica održava promocije vlastitih izdanja, organizira izložbe u prostoru knjižnice, provodi edukaciju korisnika, surađuje s Matičnom službom za visokoškolske knjižnice NSK-a u Zagrebu te Gradskom i sveučilišnom knjižnicom Osijek, sudjeluje u uredničkim poslovima u kontroli postavljenih podataka nastavnog osoblja u znanstvenoj bibliografiji CROSBI te u organizaciji znanstvenostručnih skupova na razini ustanove.

Veleučilište Baltazar ima razvijenu nakladničku djelatnost u tiskanom i elektroničkom obliku u čijoj pripremi u uredničkim poslovima knjižnica aktivno sudjeluje. Od 2002. godine objavljena su 53 naslova (ukupno 66 izdanja) tiskanih publikacija, uglavnom udžbenika iz područja društveno-humanističkih znanosti, nekoliko monografija i zbornika te pet e-skripti. Objavljeno je i osam naslova u sunakladništvu. Od 2013. tiskana se izdanja, u suradnji s nakladnikom Fotolinea, konvertiraju u e-inačice i njih 49 dostupno je za kupnju u e-obliku. Za 2020. planira se e-posudba tih izdanja za studente i ostale korisnike knjižnice. Od 2018. nakladnička politika Veleučilišta sve se više usmjerava prema objavi izvornih e-publikacija. Zasada su to e-skripte koje se nalaze na mrežnim stranicama knjižnice, a s vremenom će biti dostupni i e-udžbenici. ${ }^{91}$

\section{Zaključak}

Istraživanjem predstavljenim u ovom radu došlo se do brojnih informacija o knjižnicama u Zaprešiću i okolici te je razvidno da razvoj knjižnica tog područja

91 Prema kazivanju Gordane Šiber, voditeljice Knjižnice Veleučilišta Zaprešić. [10.4.2020.] 
prati trendove razvoja knjižnica u Hrvatskoj. O nekim je knjižnicama pronađeno više, o nekima vrlo malo izvora, ali svaku se nastojalo što kvalitetnije i sveobuhvatnije predstaviti.

Počeci razvoja knjižnica u zaprešićkom kraju vežu se uz inicijative naobraženih pojedinaca i osnivanje školskih knjižnica u drugoj polovici 19. st. Krajem 19. i u prvoj polovici 20. st. osnivaju se prve narodne knjižnice i čitaonice čiji rad prekida Drugi svjetski rat. Nakon rata vlasti inzistiraju na opismenjivanju stanovništva pa se masovno otvaraju knjižnice koje vode mladi amateri i od kojih većina nije bila dugog vijeka jer za uspješno poslovanje knjižnica tada, kao i danas, nije bio dovoljan samo entuzijazam, nužno je stručno osoblje te kontinuirano financiranje.

Najvažniju ulogu za razvoj knjižnica zaprešićkog kraja imalo je osnivanje Općinske knjižnice Zaprešić (1958.), danas Gradske knjižnice Ante Kovačića, dijela mreže Knjižnica grada Zagreba, koja je na području cijele Općine Zaprešić od 1964. djelovala kao matična knjižnica sa zadatkom širenja i propagiranja knjige vođenjem mjesne knjižnice i čitaonice u Zaprešiću, osnivanjem novih knjižnica i pružanjem stručne pomoći postojećim knjižnicama. Od šezdesetih do devedesetih godina 20. st. mrežu narodnih knjižnica zaprešićkog područja činile su: Općinska knjižnica Zaprešić (matična knjižnica), područne knjižnica Bistra, Brdovec i Prigorje Brdovečko te brojne knjižnične stanice, stacionari i ormarići za samoposudbu knjiga u radnim organizacijama, okolnim mjestima i školama. Godine 1978. na području zaprešićkog kraja s radom započinje i Bibliobusna služba Knjižnica grada Zagreba koja s vremenom uvodi sve više stanica. One zamjenjuju knjižničnu djelatnost nekadašnjih područnih knjižnica, knjižničnih stanica i stacionara koji s radom prestaju krajem osamdesetih i početkom devedesetih godina.

U vrijeme istraživanja Zaprešić i okolica mogu se pohvaliti vrlo razgranatom i živom mrežom knjižnica u kojoj djeluju 12 školskih, tri narodne i jedna visokoškolska knjižnica, kao i Bibliobusna služba s 13 stanica. Sve su knjižnice opremljene računalima i knjižničnim programima; svi knjižničari imaju potrebno obrazovanje za rad u knjižnici, stalno se usavršavaju te korisnicima nude raznolike i suvremene programe. Knjižnice međusobno izvrsno surađuju, osobito Gradska knjižnica Ante Kovačića sa školskim knjižnicama na brojnim projektima i programima na temu lokalne baštine i poticanja čitanja. No ta mreža više nije formalno jedinstvena, povezana i objedinjena oko jedne središnje knjižnice, već međusobna suradnja knjižnica ovisi o entuzijazmu i volji knjižničara te povijesno i geografski učvršćenim vezama.

Na temelju predstavljenog razvoja knjižnica u Zaprešiću i okolici može se zaključiti da je riječ o naprednom i osviještenom podneblju gdje knjižnice već gotovo dva stoljeća imaju važnu ulogu u razvoju kulturnog ozračja, poticanju čitanja i njegovanju lokalne baštine. Knjižnice Zaprešića i okolice ispunjavaju zadaće suvremenih knjižnica te nastoje ići ukorak sa svim promjenama u knjižničarstvu i društvu u cjelini. 


\section{LITERATURA}

Arhiva Gradske knjižnice Ante Kovačića. Izvještaj Gradske knjižnice Ante Kovačića za 2018. godinu. [interni dokument]

Arhiva Gradske knjižnice Ante Kovačića. Knjižni stacionari 1984./1985. [interni dokument]

Arhiva Gradske knjižnice Ante Kovačića. Narodna čitaonica i knjižnica u Prudnicama. [interni dokument]

Arhiva Gradske knjižnice Ante Kovačića. Narodna knjižnica Brdovec. [interni dokument]

Arhiva Gradske knjižnice Ante Kovačića. Zapisnik o postupku s knjigama Područne knjižnice Bistra. [interni dokument]

Arhiva Osnovne škole Jakovlje. Spomenica škole Jakovlje. [interni dokument]

Arhiva Osnovne škole Ante Kovačića. Uspomenica učione Maria Gorica. [interni dokument]

Bistra: monografija / ur. Ljiljana Dobrovšak. Bistra: Općina, 2014.

Blažić, Z. Razvoj općine Zaprešić od 1963. do 1995.: diplomski rad. Zagreb: Filozofski fakultet, Odsjek za povijest, 2019.

Crtice iz povijesti školske knjižnice. // Osnovna škola Ivane Brlić-Mažuranić Prigorje Brdovečko. [citirano: 2020-03-22]. Dostupno na: http://www.os-ibmazuranic-prigorjebrdovecko.skole.hr/skola/knjiznica/o_knji_nici.

Debeljak, M. Laduč: 1446. - 1996. Laduč: Mjesni odbor, 1996.

Kazivanje Gordane Šiber, voditeljice Knjižnice Veleučilišta Zaprešić. [10. 4. 2020.]

Kazivanje Zdenke Kamčev, nekadašnje djelatnice tvornice Jugokeramika. [7. 4. 2020.]

Knjižnica. // Veleučilište Baltazar Zaprešić. [citirano: 2020-06-17]. Dostupno na: https:// www.bak.hr/hr/referada/knjiznica

Knjižnica u pokretu: 40 godina zagrebačke bibliobusne službe / priredila Đurđica Pugelnik. Zagreb: Knjižnice grada Zagreba, 2016. [citirano: 2020-02-06]. Dostupno na: https://digitalnezbirke.kgz.hr/?object=view\&id=18971.

Laljak, S. Čitaonica u Zaprešiću 1896. godine - prvorazredno otkriće! // Zaprešićki godišnjak 10/11(2000/2001), 259-267.

Laljak, S. Dragutin Balagović (1933 - 1997). // Zaprešićki godišnjak 7(1997), 350-351.

Laljak, S. Kulturno-prosvjetni amaterizam i društvo „Tomislav” 1936. // Brdovečki zbornik 2(2003), 129-130.

Laljak, S. Općina Brdovec. // Brdovečki zbornik 4(2005), 105-110.

Laljak, S. Otkriće: čitaonica i knjižnica u Prudnicama 1933. // Zaprešićki godišnjak 13(2003), 256-261. 
Leško, N. Knjiga u radnim kolektivima. // Zaprešićke novine: glasilo Socijalističkog saveza naroda općine Zaprešić 2, 7(1980), 7.

Narodno sveučilište Zaprešić: 1958 - 1968. Zaprešić: Narodno sveučilište Zaprešić, 1968.

O školi. // Osnovna škola Jakovlje. [citirano 2020-05-29]. Dostupno na: http://os-jakovlje.skole.hr/naslovnica/o_koli/pov

Odluka o osnivanju javne ustanove Općinska knjižnica Bistra. // Službeni glasnik Općine Bistra 24(2004), 15-16.

Odluka o osnivanju javne ustanove - Općinske knjižnice Marija Gorica. // Službeni glasnik Općine Marija Gorica 177(2017). [citirano: 2020-05-29]. Dostupno na: https:// marija-gorica.hr/images/dokumenti/sluzbeni-glasnik/2017/glasnik_177.pdf

Općina Brdovec / glavna urednica Snježana Zrinjan. Brdovec: Općina, 2017.

Općinska knjižnica i čitaonica Bistra. // Knjižnica.hr. [citirano: 2020-05-28]. Dostupno na: https://www.knjiznica.hr/knjiznice/?id=305.

Osnova temeljnih pravilah javnog javnoga obučavanja za Hervatsku i Slavoniu (1849). // Anali za povijest odgoja 1, 1(1992), 125-152.

Osnovna škola Antuna Augustinčića Zaprešić: 1854. - 2004.: 150. obljetnica javne škole u Brdovcu: 100. obljetnica pučke škole u Zaprešiću: 50. obljetnica osmogodišnje škole u Zaprešiću / glavna urednica Ivanka Tomić. Zaprešić: OŠ Antuna Augustinčića, 2004.

Popis stanovništva, kućanstava i stanova 2011: stanovništvo prema obrazovnim obilježjima. Zagreb: Državni zavod za statistiku, 2016. [citirano: 2019-12-17]. Dostupno na: https://www.dzs.hr/Hrv_Eng/publication/2016/SI-1582.pdf.

Popis stanovništva, kućanstava i stanova 2011: stanovništvo prema spolu i starosti. Zagreb: Državni zavod za statistiku, 2013. [citirano: 2019-12-18]. Dostupno na: https:// www.dzs.hr/Hrv_Eng/publication/2012/SI-1468.pdf.

Pravila društva „Čitaonica” u Zaprešiću. // Zaprešićki godišnjak 10/11(2000/2001), 268-274.

Pravila Hrvatskog prosvjetnog i glazbenog društva „Tomislav” u Savskom Marofu. // Brdovečki zbornik 2(2003), 131-138.

Pravila Narodne knjižnice i čitaonice u Prudnicama Općine Brdovec. // Zaprešićki godišnjak 13(2003), 262-266.

Rajić, N. Stručna podloga za izradu novog Prostornog plana Zagrebačke županije iz područja demografije. Zagreb: Zavod za prostorno uređenje Zagrebačke županije, 2015. Dostupno na: https://www.zpuzz.hr/cms_files/2017/11/1511433301_novi-pp-zz-elaborat-demografija-2015.pdf.

Spomenica Obće pučke škole u Pušći 1848 - 1914. // Zaprešićki godišnjak 6(1996), 121-142. 
Spomenica Pučke škole Zaprešić. // Zaprešićki godišnjak 14(2004), 66-206.

Spomenica škole Brdovec. // Brdovečki zbornik 3(2004), 201-241.

Spomenica za nižu pučku školu u Jablanovcu (1903 - 1948). // Zaprešićki godišnjak 13(2003), 123-172.

Spomenica za nižu pučku školu u Luki od godine 1874. // Zaprešićki godišnjak 15/16(2005/2006), 43-158.

Standard za školske knjižnice. // Narodne novine 34, 698(2000). [citirano: 2020-03-07]. Dostupno na: https://narodne-novine.nn.hr/clanci/sluzbeni/2000_03_34_698.html.

Stipanov, J. Povijest knjižnica i knjižničarstva u Hrvatskoj: od početaka do današnjih dana. Zagreb: Školska knjiga, 2015.

Školska spomenica od škole bistranske, i njezinoga početka. // Zaprešićki godišnjak 17(2007), 217-334.

Zakon o bibliotekama. // Vjesnik bibliotekara Hrvatske 6, 3/4(1960), 75-81.

Zakon o knjižnicama i knjižničnoj djelatnosti. // Narodne novine 17, 356(2019). [citirano: 2020-03-06]. Dostupno na: https://narodne-novine.nn.hr/clanci/sluzbeni/2019 $02 \quad 17 \quad 356 . h t m l$.

Zakon od 14. listopada 1874. ob ustroju pučkih školah i preparandijah za pučko učiteljstvo u kraljevini Hrvatskoj i Slavoniji. // Sbornik zakonah i naredbah valjanih za kraljevinu Hrvatsku i Slavoniju 20(1874). [citirano: 2019-12-20]. Dostupno na: http://alex.onb.ac.at/cgi-content/alex?aid=lks\&datum=1874\&size=40\&page=413.

Zaprešić. // Hrvatska enciklopedija. Zagreb: Leksikografski zavod Miroslav Krleža, 2019. [citirano: 2019-09-09]. Dostupno na: http://www.enciklopedija.hr/natuknica. aspx?ID=66895\#top.

Zaprešić: monografija / glavna urednica Višnja Goljački. Zaprešić: Grad Zaprešić, 2015.

Zaprešić: stambeno-komunalna monografija. Zaprešić: Samoupravna interesna zajednica stanovanja i komunalnih djelatnosti, 1990. 